\title{
堀川における浮遊ゴミの移動特性に関する研究 STUDY ON THE TRANSPORT CHARACTERISTICS OF FLOATING GARBAGE IN HORI RIVER
}

\author{
武田 誠 $^{1} \cdot$ 原田守博 ${ }^{2} \cdot$ 冨永晃宏 ${ }^{3} \cdot$ 石黒鐐三 $^{4} \cdot$ 近藤貴之 ${ }^{5} \cdot$ \\ 中島佳郎 ${ }^{6} \cdot$ 吉田 均 ${ }^{7}$ \\ Makoto TAKEDA, Morihiro HARADA, Akihiro TOMINAGA, Shozou ISHIGURO, \\ Takayuki KONDO, Yoshiro NAKASHIMA and Hitoshi YOSHIDA

\begin{abstract}
1正会員 博士 (工) 中部大学准教授 工学部都市建設工学科（干487-8501 愛知県春日井市松本町1200)
2正会員 工博 名城大学教授 理工学部建設システム工学科 (†468-8502 名古屋市天白区塩釜口1-501)

3正会員 工博 名古屋工業大学教授 工学部都市社会工学科（二466-8555 名古屋市昭和区御器所町） 4非会員 庄内川ナビゲーター（テ 450-0002 名古屋市中村区名駅4-3-10 東海ビル3F）

5非会員 国土交通省庄内川河川事務所（干462-0052 名古屋市北区福徳町5-52）

6正会員 特定非営利活動法人堀川まちネット（†456-0024 名古屋市熱田区森後町7番14号沼田ビル3F) 7正会員 名古屋市環境局公害対策課（†460-8508 名古屋市中区三の丸三丁目1番1号）
\end{abstract}

In this study, the kind and the transport characteristics of floating garbage are examined in Hori River located in center part of Nagoya city. By field observation on floating garbage in Hori River, it was found that more than $70 \%$ in floating garbage is natural garbage, a lot of artificial garbage appears in downstream area and the most natural garbage are dead trees and grasses entering into Hori River. In addition, from investigation on floating garbage in water area of Matsushige lock, it was seen that water area of Matsushige lock affected prolongation of floating garbage in Hori River. By numerical analysis, it was seen that the transport characteristics of floating garbage in water area of Matsushige lock is the influence of water flow caused by density change of tidal phenomena in Hori River.

Key Words : Floating garbage, Hori River, Transport characteristics, Field observation, Numerical simulation

\section{1. はじめに}

名古屋市の中心部を南北に流れる堀川は, 名古屋城築 城にあわせて，資材の運搬のために掘削された人工河川 であり，当時は沿川に人々が集い賑わっていた。高度経 済成長期には，他の都市河川と同様に工場排水などによ る水質悪化が進行し，BOD值で50mg/lを超え悪臭が漂う など, 深刻な水環境の悪化が生じた. その後, 水質・悪 臭など様々な公害に対する水質污濁防止法が施行され, 排水規制，へドロ浚渫，下水道整備などの対策により， 水環境の改善が進んだ. しかし，未だ水質・悪臭・ゴミ の問題は十分に解決されておらず, 市民からの水環境改 善の要望は高い.

2006年に, 名古屋市堀川の再生を目的として, 産官学 民が一同に会して堀川の活用・水環境改善を議論する

「堀川再生のための連携プロジェクト2006」が設立され た. その中では，以下に示す5つのグループが構成され，
1年を通じたワークショップ，現地調査など精力的な活 動が行われた。

第 1 グループ「堀川を活かした魅力あるまちづくり」

第 2 グループ「堀川に関わる連携方策」

第 3 グループ「水質の感覚的評価と浄化方策」

第 4 グループ「堀川の良さの再発掘」

第 5 グループ「環境学習と情報発信・PR」

著者らは，第 3 グループに属し，堀川の水環境につい て調査・検討を進めてきた. 当初, 堀川の水質改善策の 提言までも念頭に置いた水質問題を取り扱うべきである との指摘もあったが，本ワーキンググループが専門家の みで構成されていないこと, 市民との協働といら観点か ら分かり易い現象を対象にしたいといら要望があり, 議 論を重ねて，感覚的評価を重視した「におい」「ゴミ」 に焦点を絞り検討した. 本報では，得られた成果のうち， 「ゴミ」に関する知見をまとめ, 堀川における浮遊ゴミ の種類と特徵, 移動特性, さらに, 想定される対策につ いて報告する. 


\section{2. 堀川の浮遊ゴミの特性}

\section{（1）調査方法}

堀川の浮遊ゴミの種類および量を把握する目的で，大 潮である平成18年8月25日に, 図-1に示寸東田幡橋(堀川 河口から $13.1 \mathrm{~km})$ ，五條橋 $(10.0 \mathrm{~km})$ ，日置橋 $(7.9 \mathrm{~km})$, 御 陵橋 (4.4km) で，下げ潮時 (6時〜13時) と上げ潮時 (13時 〜19時) に橋の中央(御陵橋は両岸) で写真-1のようなゴ ミ網（入り口の大きさ; 縦 $40 \mathrm{~cm}$ ，横 $40 \mathrm{~cm}$ ，目幅 $2 \mathrm{~mm}$ ）を 設置し，浮遊ゴミを採取した。橋毎に得られたゴミを乾 燥させた後ゴミの種類と質量を計測した。なお，東田 幡橋は名古屋工業大学富永研究室が，五條橋，日置橋は 中部大学都市水工部門が，御陵橋は名城大学原田研究室 が調查を実施した．また，季節による比較を行う目的で 大潮である平成18年12月5日にも日置橋において同様の 観測を行った。

\section{(2) 調査結果および考察}

図-2に橋毎のゴミの総質量を示す，本図から，上流は ゴミの量が少なく下流にいくほどゴミの量が多くなるこ とが分かる．特に日置橋上流では下げ潮に比べて上げ潮 の方がゴミの量が多いが，これは，後述する松重閘門水 域部の存在による堀川の浮流ゴミの移動特性に関係する ものと考える．また，日置橋での平成18年8月25日と平 成18年12月5日のゴミの量に大きな差がある。これは, 平成 18 年 8 月 22 日に日雨量 $33.5 \mathrm{~mm}$ （最大時間雨量 17.5mm）の降雨があり側岸部や都市内にあったゴミが 堀川水域に流入したことが原因と考えられる.

つぎに，枯葉など自然の物を「自然ゴミ」，ビニール など人工の物を「人工ゴミ」と定義し，橋毎のそれらの 比率を図-3に示寸．本図から，人工ゴミよりも自然ゴミ が多く平均で7割を超えること，下流に向かうにつれて 人工ゴミが多くなっていることが分かる．また，自然ゴ ミは，水草のように川の内部から発生するゴミより，落 ち葉や枯れ木のような川の外部から流入するゴミの方が 多かった．さらに，人工ゴミの中ではビニール類のゴミ が多く見られ，下流に行くほどタバコの吸款が目立った。 上中流部は護岸に草木が多く，また，中下流部では通行 人が多くビニール類やタバコが捨てられやすい環境であ る.さらに, 堀川の浮遊ゴミは上下流への輸送を繰り返 しながら，だんだんと流下寸る感潮河川の特徴を有して いる.このようなゴミ流入およびゴミ輸送の特性が調查 結果に表れたものと考える. また，枯葉などの自然ゴミ が多いことから，護岸の整備・除草に伴う草木の流入抑 制が，堀川の水環境改善に効果があることが推察される.

平成18年8月25日には，“ねずみ”などの死骸が多数 浮いていた，これは，名古屋市内の合流式下水道内に生 息している “ねずみ”が平成18年8月22日の大雨による 急な管内増水に逃げ遅れた結果であろう。長期間死骸が

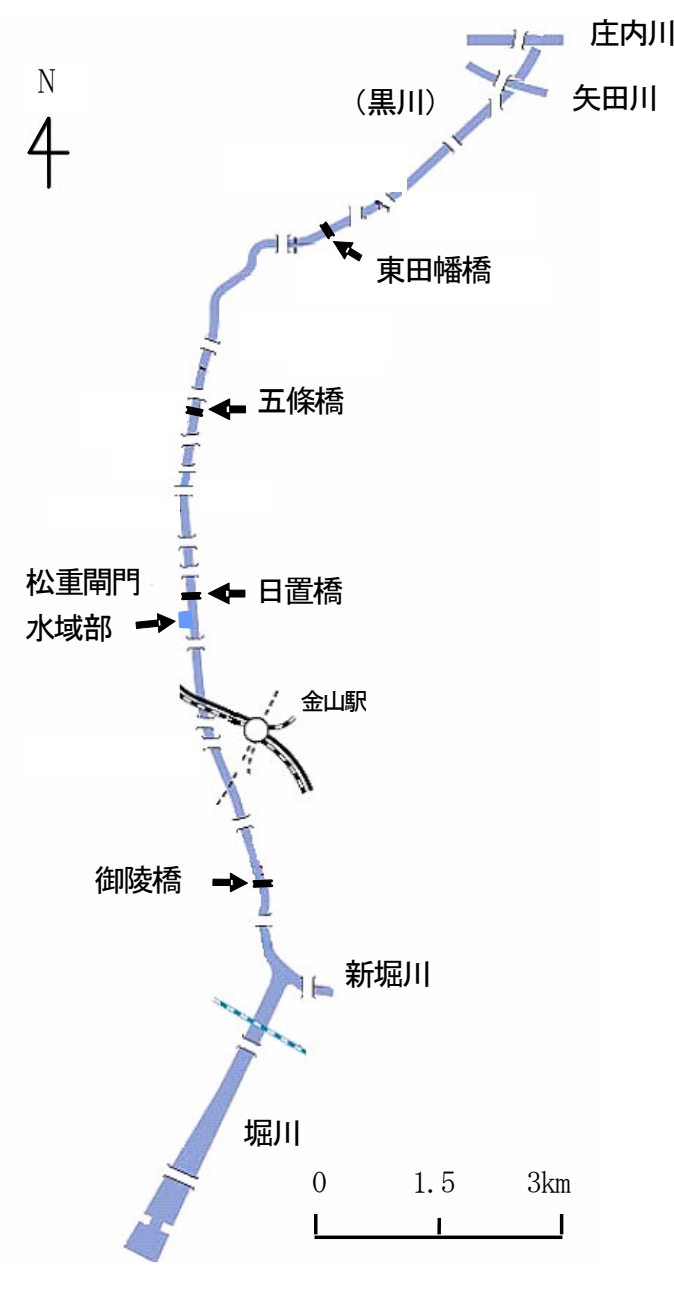

図-1 観測場所

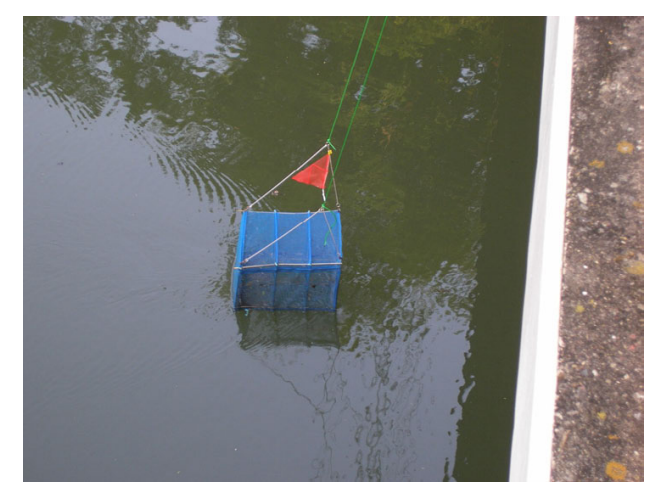

写真-1 ゴミ網の設置状況

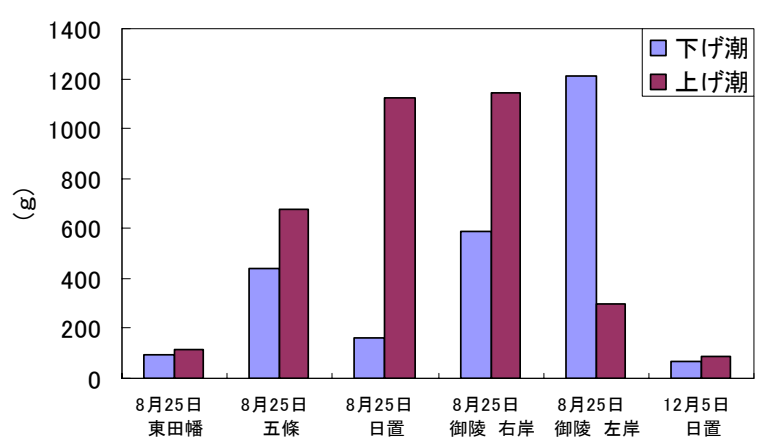

図-2＼cjkstart橋毎の浮遊ゴミの質量 


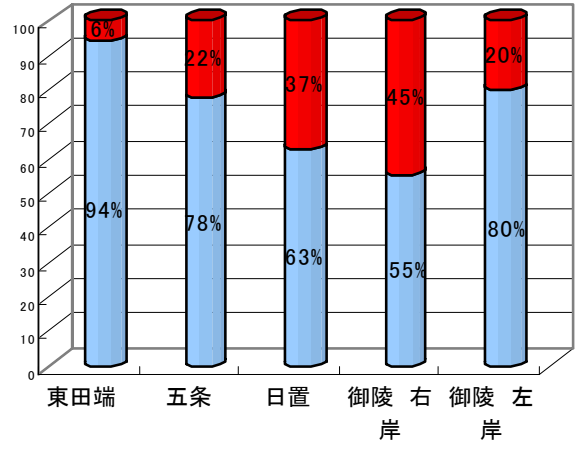

下げ潮の場合

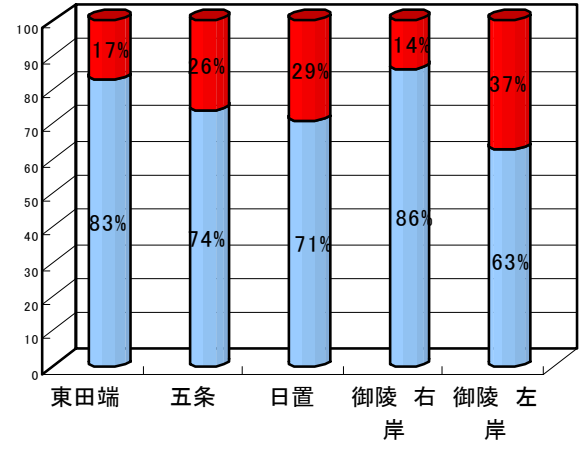

上げ潮の場合
ロ人エゴミ

口自然ゴミ

図-3 人エゴミと自然ゴミの割合

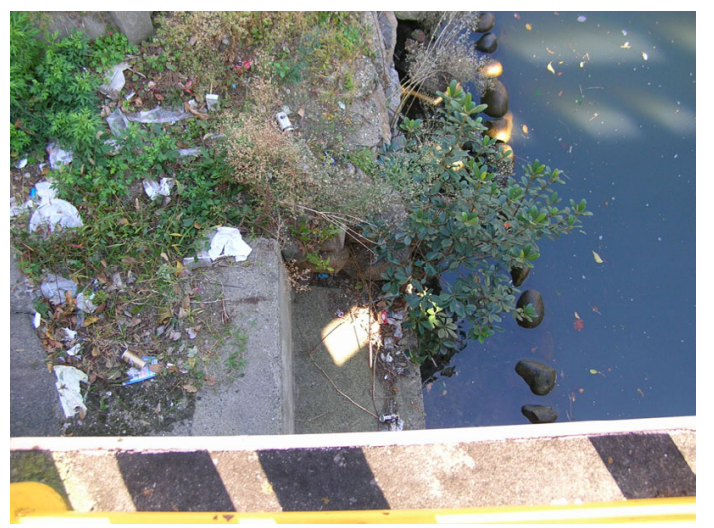

写真-2 側岸に溜まる浮遊ゴミ

浮いている状況は問題であることから，雨水吐における 死骸の流出抑制や早期の回収などの対策が必要であろう。

枯葉や枝などは本来川にも在るもので，これをゴミと して取り扱うことは奇異に感じるかもしれない. しかし， 集積した枯葉や枝が長期に漂うことは不快であり，親水 性の面からもマイナスである.さらに，へドロの堆積に よる悪臭，水質悪化が大きな問題となっており，このへ ドロ生成の一要因として, 枯葉や枝の川底への堆積があ ることから，堀川では枯葉や枝などを「自然ゴミ」とし て取り扱う必要があると考える。 また，ゴミは断面内を 均等に分布して流れるわけではないため, ここで示され た值は目安とみなすべきであろうが，浮遊ゴミに関する 定性的な状況は把握できたと考える.

\section{3. 堀川の浮遊ゴミの移動特性}

\section{（1）日置橋直下の浮遊ゴミ}

堀川へ流入したゴミは，潮汐変動に伴い堀川内を行き 来し, 長く留まっている状況を良く目にする. そこで, 浮遊ゴミの移動に関する調査を行った。平成18年11月9 日8時～18時（中潮）と平成18年12月 5 日8時 30 分～18時 （大潮）に，目視できるゴミについて日置橋直下の出現 位置を調查した. 草などの目視しにくいものは過小評価

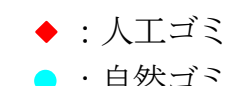

：自然ゴミ

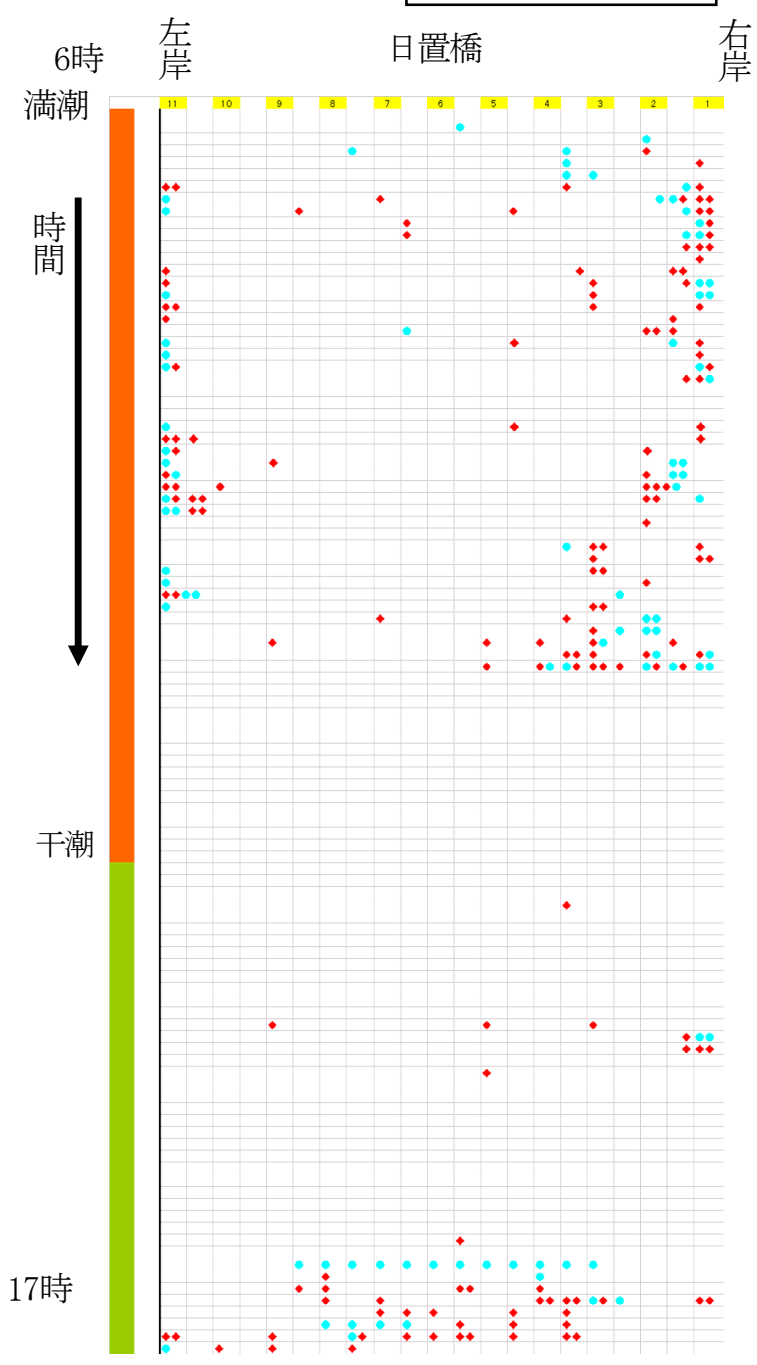

図-4 日置橋直下のゴミの位置（平成18年11月9日）

されている可能性はあるが，可能な限り詳細に記録した。

図-4に調査結果の一例を示寸，なお，図中の菱形は人 工ゴミを，丸は自然ゴミを表しており，下方向に時間が 経過している. 本図から, 干潮では, ゴミが少なくなっ ていることが分かる.これは，写真-2にもあるように， 


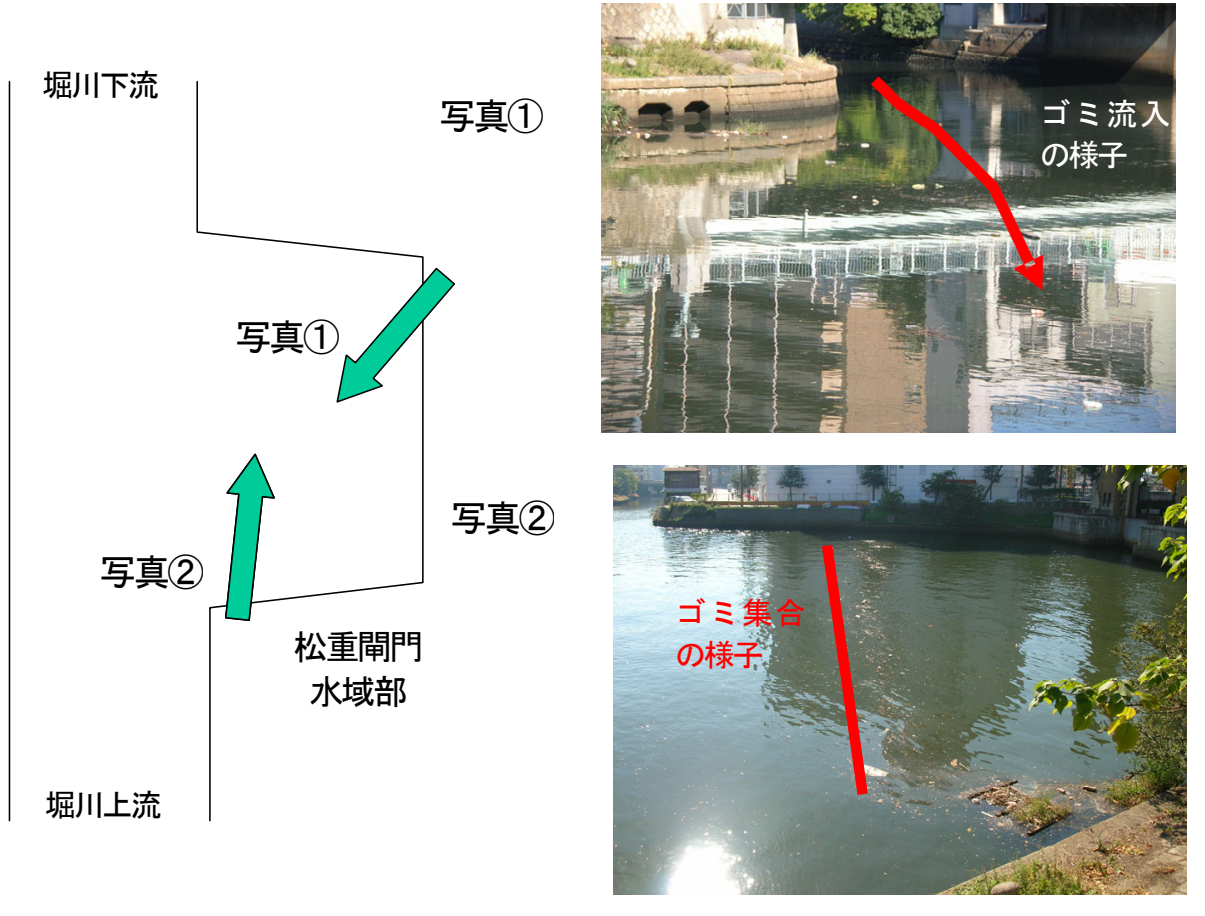

写真-3 松重閘門水域部のゴミの集積（下げ潮時）



写真-4 日置橋下流の浮遊ゴミの様子 (撮影時間 : 16:50)

水位が低下寸るとともに側岸部にゴミが溜まり，水面を 漂わなくなったことが考えられる，また，水位上昇時に は再び水面へ戻り, 輸送を繰り返すものと推察される. 下げ潮の場合にはゴミが両岸に沿って多く流れており， 特に右岸側が多いことが分かる。，一方，上げ潮の場合で はゴミが川全面に広がっている．同様な状況が平成18年 12月5日にも観測された。 ゴミが両岸に沿って流れる現 象は，水位上昇に伴う浮遊ゴミの出現や側岸からゴミが 流入しやすいこと，河川線形の影響などが原因と考えら れる.また，上げ潮のゴミが川全面に広がる現象は図-1 に示寸日置橋下流の松重閘門水域部の影響を受けている と考えた．そこで，平成18年11月9日と平成18年12月5日 には，松重閘門水域部のゴミ移動も調查した.

\section{（2）松重閘門水域部のゴミ輸送}

日置橋の下流に位置する松重閘門水域部は，閘門が機

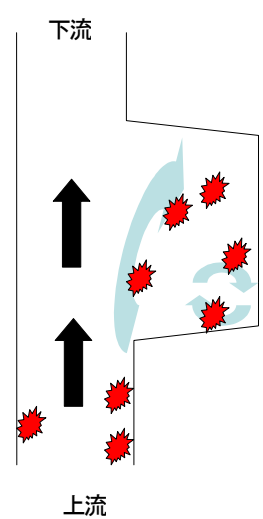

$11: 00 \sim 11: 40$

図-5＼cjkstart松重閘門水域部の浮遊ゴミの移動

能していたときには，船泊まりとして利用されていた場 所である. 写真-3に平成18年11月9日の松重閘門水域部 におけるゴミ集合の状況を示す。下げ潮時には堀川から 水域部一流入するゴミが認められ，流入したゴミは水域 部内を移動しながら集合していた，また，上げ潮におけ る日置橋から堀川下流の様子を写真-4に示寸．写真撮影 時は夕方(16時50分)であり，見やすくするために「明る さ」と「コントラスト」を上げて表示している. この写 真から, 水域部から流出したゴミが断面中央部を遡上し ていることが分かる．松重閘門水域部のゴミ移動の概念 図を示せば，図-5のようである，下げ潮では，右岸側を 流下してきたゴミが水域部一流入する様子が見られ，観 測した時間内では，その水域部から下流一流出する様子 は見られなかった。 また，上げ潮時には，水域部で集合 したゴミが堀川へ流出する現象が見られ，特に17時には まとまったゴミが堀川へ流出する現象がみられた。この 
ことは，日置橋において17時に多くのゴミを観測したこ とと関連付けられる。 また，平成18年12月8日にも同様 な松重閘門水域部のゴミ輸送が観測された。したがって， 堀川の浮遊ゴミの一部は，堀川中流と松重閘門水域部の 間を行き来しており，松重閘門水域部の存在が堀川にお ける浮遊ゴミの長期化に寄与している可能性がある.

\section{（3）GPSを用いたゴミの移動調査}

堀川における浮遊ゴミの移動状況を確認寸るために, GPSを乗せた人工ゴミを堀川に投下し、15分毎のGPSの 位置履歴データを取得した。観測期間は平成19年1月9日 の6時から平成19年1月11日の10時までとし、納屋橋をス タート地点とした．平成19年1月11日10時に日置橋で流 下する人工ゴミを回収した。

図-6に名古屋港の潮位を、図-7にGPSの移動軌跡をX 軸を経度、Y軸を緯度として示す。図-7より、人工ゴミ は上げ潮1から上げ潮5にかけてだんだんと南方に移動し ていることがわかる。また、下げ潮 3 から上げ潮5までは ほとんど同じ水域を動いているようであり、その範囲で 北上、南下をくり返していることがわかる。これらの位 置の南端は松重閘門であり，平成19年1月11日に松重閘 門の上流に位置する日置橋で人工ゴミを回収したことか らも，人工ゴミは堀川中流と松重閘門水域部を行き来し ていることが改めて示され，松重閘門水域部が堀川のゴ ミ輸送に影響を与えていることが確かめられた.

このことから, 大雨後に堀川に大量に流入したゴミは, 下げ潮時には，一旦松重閘門水域部一集合されるが，上 げ潮時のゴミの流出前にゴミを回収すれば，より効率的 な浮遊ゴミの回収が行える. さらに, 水域部入り口付近 に開閉式のフェンスを設置し，ゴミが流入する際には開 けておき，ゴミが流出する際に閉めて，ゴミを確保する ことも考えられる.このように松重閘門水域部の水理機 能を十分に活用し，浮遊ゴミの回収を行うことは，十分 に実現可能な対策であろう。

\section{（4）松重閘門水域部における浮遊ゴミ移動の数值解析}

松重閘門水域部における浮遊ゴミの移動特性（下げ潮 に流入，上げ潮に流出）の要因究明のために感潮域の密 度変化を考慮した 3 次元数值解析を実施した. 用いた解 析モデルの基礎式は, デカルト座標の連続式, 運動量方 程式（鉛直方向は，静水圧の式），塩分の収支式，密度 の状態方程式である。簡単のために堀川の河口から $4.4 \mathrm{~km} \sim 13.6 \mathrm{~km}$ 範囲を直線と仮定し，図-8のように計 算領域を設定した。 なお，本図のy軸はx軸のスケールの 10倍として表示している．鋁直方向には0.5mの格子を配 置し, 水位に応じて計算格子を増減させた。 ただし，上 流側や側岸部で，地盤高が高いことにより河口から連な る水位の存在する表層と同じ高さの表層とならない場合 には，平面二次元解析を適用しドライベッドの取り扱い も考慮している. 境界条件として，上流端に $0.3 \mathrm{~m}^{3} / \mathrm{s}$ の淡

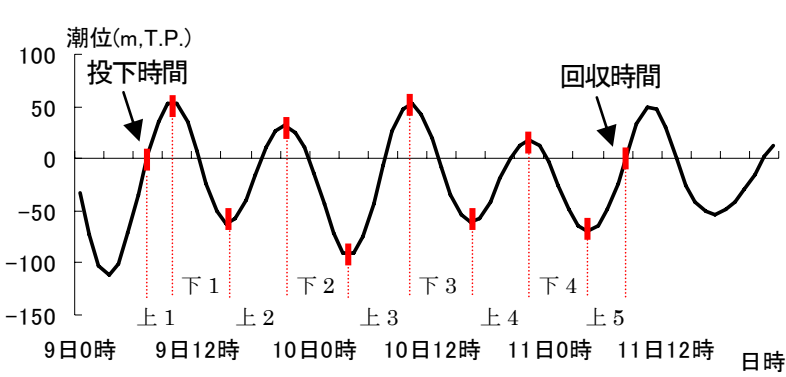

図-6 名古屋港潮位（平成19年1月9日〜1月11日） (※上げ潮1を上1、下げ潮1を下1と示す）

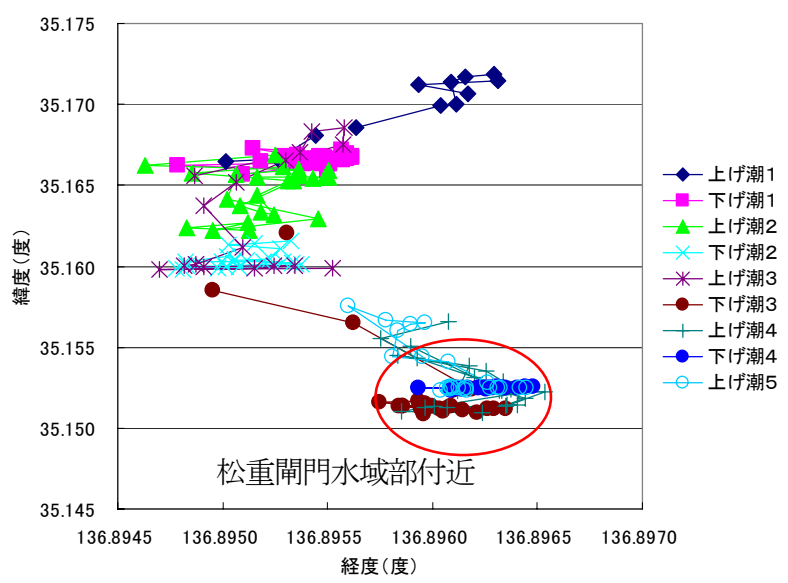

図-7 GPSの移動軌跡

水流量を, 下流端に振幅 $1.0 \mathrm{~m}$, 周期 12 時間の潮位変動を 与えた。平成18年8月 25 日 6 時の2 (1) の4つの橋の観測 データを基に初期の塩分分布を与え, 水温は一定

$\left(28.8^{\circ} \mathrm{C}\right)$ とし，下流端には表層10.7psu，中間層19.4psu， 底層22.7psu，その間を線形補間した塩分分布を与えた。 検討には4日間の前駆計算の後の1周期分の解析結果を用 いた．さらに，表層の流速值を用いてゴミの移動をラグ ランジュ的に計算した.

解析結果の一例として, 図-9に密度変化が無い場合と ある場合の図-8の拡大領域における上げ潮と下げ潮の表 層流速分布を示寸. 図中の時間は計算開始から4 日後を ゼロとして示している. 本図から, 密度変化が無い場合 には，水域部に流入出する流れが明瞭に現れていないが， 密度変化がある場合には，下げ潮時には堀川から水域部 へ流入する流れが，上げ潮時には水域部から堀川へ流出 する流れが生じていることが分かる．上げ潮の場合，本 川と水域部を比べれば, 松重閘門付近の堀川本川が水域 部に比べて早く密度が大きくなるため, 底層では, 本川 から水域部へ向から流れが生じ，それを補うように表層 では水域部から本川へ流れが生じる，一方，下げ潮の場 合, それとは逆に，本川の方が先に密度が小さくなるた め, 底層では密度差に起因する水域部から本川へ向かう 流れが生じ，それを補うように表層では本川から水域部 へ流れが生じる.また, 図-10に密度変化が無い場合と ある場合の上げ潮と下げ潮のゴミの移動を示す。なお， 下げ潮の場合は6時に図-8の矢印で示寸範囲に，上げ潮 


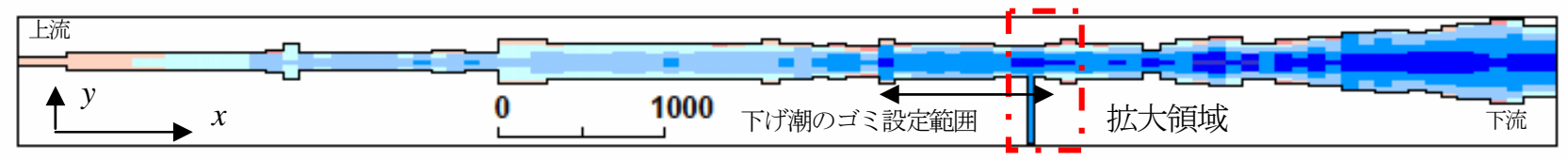

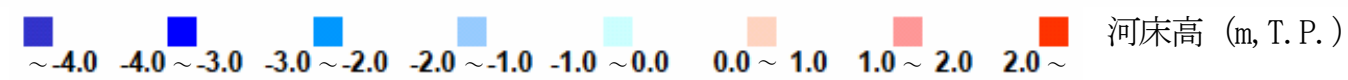

図-8 計算領域
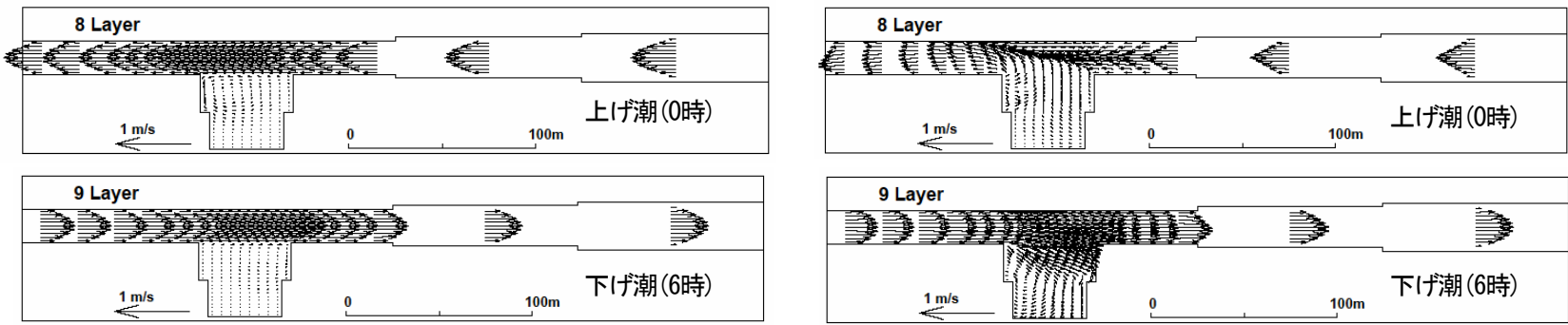

密度変化が無い場合

図-9 表層の流速分布
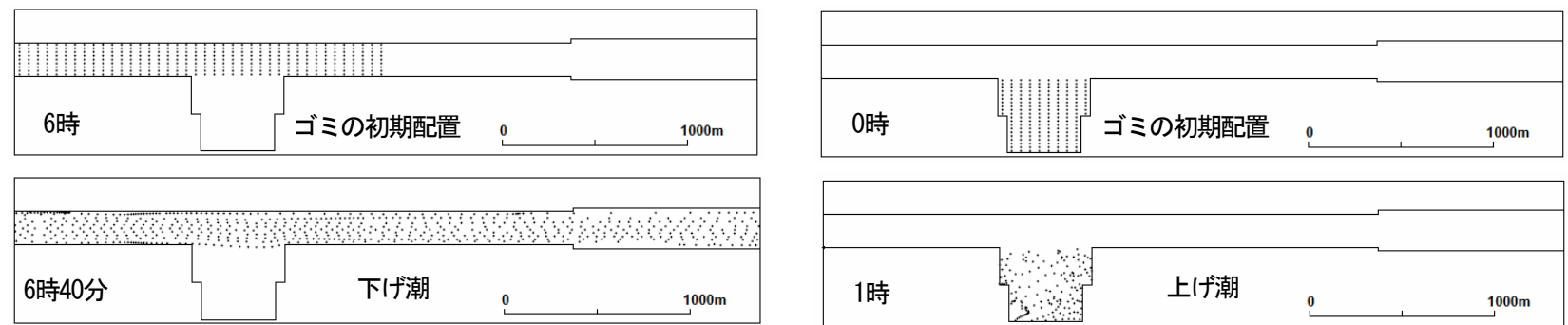

密度変化が無い場合
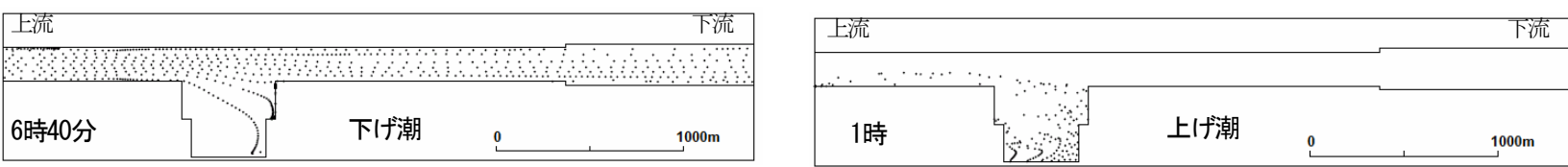

密度変化がある場合

図-10 松重閘門水域部のゴミの移動

の場合は0時に松重閘門水域部にゴミを配置した。図-10 より，密度変化が無い場合には，水域部に流入あるいは 流出するゴミは非常に少ないことが分かる，一方，密度 変化がある場合には，下げ潮時に右岸側にあったゴミが 水域部一流入し，上げ潮時に水域部の下流側からゴミが 流出している様子が分かる. 本図における流入時の水域 部の線状のゴミ集合の様子や，水域部下流側からのゴミ 流出などは観測結果と定性的に類似している. したがっ て, 感潮部の密度変化に伴う表層の流れが松重閘門水域 部のゴミの輸送に大きく影響していることが推察される.

\section{4. おわりに}

得られた結果をまとめれば，以下のようである.

1）堀川を浮遊しているゴミの中で自然ゴミが約7割を占 め，下流に行くほど人工ゴミが多い．また，自然ゴミは， 枯れ木や草などの堀川の外部から流入するものが多い.

2）日置橋直下の浮流ゴミは，下げ潮の場合側岸部を流
下し，特に右岸側を流れるゴミが多い.また，上げ潮の 場合川全面を遡上する.

3）日置橋で観測されたゴミの輸送には，その下流に位 置する松重閘門水域部が影響を与えており，下げ潮では， 右岸側を流れた浮遊ゴミが水域部へ入り，そこで集合し て，上げ潮では堀川の全面へ流出する様子が確認された. 4）GPSを登載した人工ゴミを流した場合，堀川中流域と 松重閘門水域部を行き来する状況が確認された。

5）松重閘門水域部は，堀川の浮遊ゴミの長期化に寄与 し，堀川は他の河川に比べて，浮遊ゴミが長期帯在し， ゴミが目立つ川であることが明らかとなった。

6）松重閘門水域部の浮遊ゴミの移動は，感潮河川の密 度変化の影響を強く受けた流れによって生じていること が，数值解析を用いた検討により示された.

7）得られた知見から有効なゴミ対策が想定された. 最後に，本研究は，土木学会「流域管理と地域計画の連 携方策に関わる共同研究」のもとで行ったものであり， 記して謝意を表する.

(2007. 9. 30受付) 